\title{
VYSOKÉ ŠKOLY JAKO AKTÉR REGIONÁLNÍHO ROZVOJE
}

\section{UNIVERSITIES AS AN ACTOR OF REGIONAL DEVELOPMENT}

\author{
Mgr. JAN ZVARA ${ }^{1}$ \\ ING. PETR ŠS $\breve{S} I N K A^{2}$ \\ JAKUB RYBÁR ${ }^{3}$ \\ Mgr. Petr HUdEČEK ${ }^{4}$
${ }^{1}$ Geografický ústav $\mid{ }^{1}$ Department of Geography
Masarykova univerzita Masaryk University
$\triangle$ Kotlářská 2, 61137 Brno, Czech Republic
E-mail:66297@mail.muni.cz \\ Přirodovédecká fakulta Faculty of Science \\ \begin{tabular}{l|l}
${ }^{2}$ Katedra regionální ekonomie a správy & ${ }^{2}$ Depart. of Regional Economics and Administration
\end{tabular} \\ Ekonomicko-správní fakulta Faculty of Economics and Administration \\ Masarykova univerzita Masaryk University \\ $\triangle$ Lipová 41a, 60200 Brno Czech Republic \\ E-mail:206708@mail.muni.cz \\ ${ }^{3}$ Fakulta sociálnich studii ${ }^{3}$ Faculty of Social Studies \\ Masarykova univerzita Masaryk University \\ $\triangle$ Joštova 10, 60200 Brno, Czech Republic \\ E-mail:62946@mail.muni.cz
Právnická fakulta Faculty of Law
Masarykova univerzita Masaryk University
$\triangle$ Veveři 70, 61180 Brno, Czech Republic
E-mail:144123@mail.muni.cz \\ \begin{tabular}{l|l}
${ }^{4}$ Ústav dovednostni výuky a inovace studia & ${ }^{4}$ Institute of Legal Skills and Innovation of Studies
\end{tabular}
}

\begin{abstract}
Anotace
Vysoké školy jsou stále významnějšim aktérem v regionálním rozvoji. Jejich dynamický rozvoj v posledni dekádě se projevuje strmým nárůstem počtu studentů a klade nové nároky na městskou infrastrukturu, mobilitu a funkce. Př́spěvek si klade za cíl poukázat na vliv př́tomnosti studenti̊ na rozvoj města Brna a ospravedlnit tak nutnost zahrnuti spolupráce s vysokými školami do strategického plánováni mésta. Popsány jsou teoretické prístupy $k$ vysokoškolskému prostředi v kontextu jeho působeni na rozvoj měst (včetně modelů zapojeni univerzit do mistního prostředí); dále jsou zdůrazněny pro město nejviditelnějši dopady a interakce v podobě prosté přitomnosti vysokoškolských studentů v Brně. Za účelem zmapováni těchto dopadů vznikl dotazník pro studenty s cílem popsat vzájemnou interakci města a studentů a vyvodit z ní relevantni závěry pro městské strategické plánování. Nejzajímavějši výstupy dotazníku budou v článku predstaveny.
\end{abstract}

\section{Klíčová slova}

vysoké školy, regionální rozvoj, Brno

\section{Annotation}


There is a growing importance of universities as an actor in regional development. Their dynamic development places new demands on city infrastructure, mobility and functions due to steep growth of number of students. The submitted article aims to point out impacts of presence of students on development of Brno and to excuse necessity of inclusion of cooperation among city and universities into city strategic planning. Theoretical approaches to university environment will be presented in context of its impacts on urban development (models of involvement into local environment included). Focus is given on minor but the most visible impacts and interactions of simple presence of university students in Brno. A questionnaire was created for students aimed to describe mutual interactions between students and the city for mapping those impacts. The most interesting outputs of this questionnaire will be presented.

\section{Key words}

universities, regional development, Brno

JEL classification: 125, O15

\section{Úvod}

Vysoké školy jako nejvyšší článek vzdělávací soustavy jsou unikátní instituce, které se již od svého vzniku koncentrují do měst. Ta je tradičně podporovala, protože jim zajišt'ovaly př́sun vzdělaných lidí a zvyšovaly jejich prestiž. Př́tomnost vysokých škol má na města řadu dopadů a ovlivňuje jejich rozvoj. Se změnami ve společnosti po druhé světové válce souvisí i zvýšení důrazu na vysokoškolské vzdělání. To vedlo ke vzniku mnoha nových vysokých škol a $\mathrm{k}$ vytvoření prostorově husté sítě vzdělávacích center. Vysokoškolské prostředí přitom dál nabylo na významu, především díky rozvoji znalostní ekonomiky, tedy systému založenému na konkurenční výhodě v podobě vlastnictví unikátních znalostí, vědomostí a poznatků. Vysokoškolský sektor se postupně stal významným faktorem přispívajícím $\mathrm{k}$ regionálnímu rozvoji jak prostřednictvím tzv. znalostní ekonomiky, tak prostřednictvím prosté koncentrace studentů, kteří svojí př́tomností působí na městské prostředí a značně jej ovlivňují. To s sebou nese nutnost zahrnout tento fakt do strategických úvah při plánování dalšího rozvoje těchto měst.

Město Brno je unikátní nejen svojí polohou, ale zejména vysokou koncentrací vzdělávacích a vědecko-výzkumných kapacit. Vysoké školy a vědecká pracoviště jsou samostatnými subjekty, které hospodaří s vlastním rozpočtem a plánují svůj rozvoj. Zároveň se vesměs jedná o významné zaměstnavatele v regionu. Počet vysokoškolských studentů v Brně již přesáhl 8 desítek tisíc. Toto jsou některé z př́čin velmi intenzivních interakcí, ke kterým dochází mezi městem a jednotlivými vzdělávacími a vědecko-výzkumnými institucemi na poli místního rozvoje. Tyto interakce jsou nekoordinovány a nepodléhají žádnému sledování, evidenci či zavedenému systému.

Cílem předkládaného př́spěvku je poukázat na vliv přítomnosti studenti̊ na rozvoj města Brna a ospravedlnit tak nutnost zahrnutí spolupráce s vysokými školami do strategického plánování města. Př́spěvek nejprve popisuje teoretické př́stupy $\mathrm{k}$ vysokoškolskému prostř̌edí $\mathrm{v}$ kontextu jeho působení na rozvoj měst (včetně modelů zapojení univerzit do místního prostředí). V další části je kladen důraz na dílčí, ale pro město nejviditelnější dopady a interakce v podobě prosté př́tomnosti vysokoškolských studentů v Brně. Za účelem zmapování těchto dopadů vznikl dotazník pro studenty s cílem popsat vzájemnou interakci města a studentů a vyvodit z ní relevantní závěry pro městské strategické plánování. Nejzajímavější výstupy dotazníku budou v př́íspěvku představeny.

\section{Př́stupy ke zkoumání vysokoškolského prostředí}

Zkoumání vysokých škol a vysokoškolského prostředí není jednoznačnou doménou jedné vědy. Dochází zde k překryvu různých oblastí, nicméně základní př́stupy vycházejí ze tř̌i směrů:

- vysoká škola jako součást systému vzdělávání, 
- vysoká škola jako ekonomický subjekt,

- vysoká škola jako společenství lidí, především studentů (v kontextu zaměření prríspěvku jde o klíčový faktor).

Z pohledu univerzity jako vzdělávací instituce se autoři zabývají otázkami vývoje vysokoškolského systému (Trow, 1974), jeho prostorovou distribucí (Ryba, 1971) a lokalizací (Schofer, 1975).

Jiný pohled bere univerzitu jako jeden z ekonomických subjektů. Obecnou rovinou se zabývají studie S. Elliotta a kol. (1988) nebo J. J. Sigfrieda a kol. (2005), které ukazují možnosti měření vlivu univerzit na ekonomiku. Další práce se věnují jednotlivým oblastem jako je zapojení univerzit do znalostní ekonomiky (Conceição a Heitor, 1999), transferu technologií (Mowery a kol., 2004), nebo propojení vysokoškolského a privátního prostředí (Perkmann a Walsh, 2007).

Ze sociálních věd vychází zájem o vysokoškolské instituce jako společenství lidí, které se odlišuje od svého okolí. Předmětem studia je především studentská komunita, která s rozvojem masového vysokoškolského vzdělávání v druhé polovině 20. století nabyla na významu. Velká část témat úzce souvisí se sociální geografií a např́íklad D. P. Smith (2009) je souborně řadí pod tzv. „student geographies“. Geografický výzkum se pak zaměřuje především na problematiku mobility v různých úrovních a na oblasti působení studentů ve městě. Migrační proudy mladých lidí při příchodu na univerzitu a po jejím absolvování zkoumá např. O. Duke-Williams (2009). Díky rozšíření vysokoškolského vzdělávání se změnil poměr mezi studenty, kteři při přechodu na univerzitu opouštějí domov a těmi, kteří studují $\mathrm{v}$ místě bydliště. $\mathrm{O}$ rozdílech mezi těmito dvěma skupinami pojednávají práce C. Holdswortha $(2008 ; 2009)$. Mezinárodní dimenzí studentské mobility se zabývá např. J. L. Waters (2009), v evropském měřítku pak L. Mechtenberg a R. Strausz (2007). Velkému zájmu se těší zkoumání studentské komunity v městském prostředí. Vliv studentů na město zkoumá např́klad J. Allison (2006) nebo M. Munro a kol. (2009). Po nárůstu počtu studentů se začaly zvýrazňovat určité problémy, především v oblastech bydlení a vlivu studentů na určité lokality. Problematiku studentifikace, jako zvláštního př́padu gentrifikace řeší např́ílad P. Hubbard (2009) nebo D. P. Smith (2005, 2008); otázkami bydlení se pak zabývá H. Christine a kol. (2002).

Všechny tři uvedené směry se pak spojují v pohledu na univerzity jako aktéry regionálního rozvoje. Těmito otázkami se zabývají ve svých pracích např́klad J. Goddard a P. Chetterton (1999), A. P. Russo (2003) a P. Arbo a P. Benneworth (2007).

\section{Historický vývoj vztahu vysokého školství a regionálního rozvoje}

V souvislosti se třemi výše popsanými směry prodělalo celosvětově vysokoškolské prostředí nejzásadnější změny v období státních intervencí po druhé světové válce. Vysoké školství bylo zapojeno do politiky regionálního rozvoje, především v oblasti lokalizace nových institucí či jejich decentralizací a pak také financování. Výsledkem mělo být spíše vyrovnávání meziregionálních rozdílů než cílená podpora místního rozvoje. $\mathrm{S}$ těmito snahami souvisí i výrazná masifikace ${ }^{1}$ vysokoškolského vzdělávání, která se začala šiřit od konce 50. let z USA do dalších zemí. Jejím nejviditelnějším projevem bylo rychlé zvyšování počtu studentů, tedy základního kamene každé vysokoškolské instituce. Následovaly další změny vyvolané at' už př́ímo či nepřímo tímto jevem, jako byl vznik nových škol či jejich poboček, rozšiřování těch stávajících, změny v nabídce oborů, změna sociálního složení studentů a jiné. Došlo také k měřítkovému posunu významu vysokých škol vůči svému okolí. Až do této doby se počet akademických pracovníků a studentů počítal v jednotlivých městech v řádu tisíců, po průběhu masifikace dosahoval již desítek tisíc. Na konci 60. let došlo také k významné změně atmosféry univerzitního prostředí projevující se demokratizací, radikalismem, sociální angažovaností a myšlenkovým otevřením univerzitního prostředí (Delanty, 2002). To vše se odrazilo na vztazích mezi univerzitami a městy. Díky růstu vysokých škol se některé tradiční problémy jako studentské bydlení výrazně prohloubily, některé - jako nárůst dopravy - naopak nově vyvstaly.

\footnotetext{
${ }^{1}$ Masifikací se v tomto případě myslí zpř́istupnění vysokoškolského studia širším vrstvám společnosti.
} 
Obrat ve vztahu univerzit a státu přišel ke konci 70. let. Dosavadní regionální politika se ukázala být neúčinnou jak $\mathrm{v}$ př́padě lokalizace jednotlivých škol, tak i v př́padě financování. Došlo sice k prostorovému rozptýlení jednotlivých institucí, nicméně celkově byly posíleny velké univerzity. Další ránu dosavadnímu systému přinesla deindustrializace. Stará průmyslová města se začala ekonomicky propadat a s tím souvisel i úpadek místního vysokého školství. Nejhưře byly postiženy školy orientované na tradiční průmysl, nicméně problémy se nevyhnuly ani dalším institucím. Nová koncepce přišla s nástupem konzervativní politiky 80 . let. Stát přestal plošně dotovat systém vysokého školství a finanční zdroje začal přidělovat podle kvality jednotlivých škol. Univerzity byly podporovány $\mathrm{v}$ získávání prostředků pomocí spolupráce se soukromými subjekty. Ve městech se silným zastoupením upadajících průmyslových odvětví byl podporován rozvoj vysokoškolských oborů zaměřených na progresivní průmysl. Zatímco $\mathrm{v}$ předchozím období viděly místní instituce přínos vysokých škol především $\mathrm{v}$ př́livu státních peněz a příchodu mladých lidí, nyní se jejich pozornost obrátila právě na oblast spolupráce s privátním sektorem. Vysoké školství se tak stává důležitou součástí ekonomického rozvoje měst (Goddard, 2008).

S nástupem globalizace se v oblasti terciérního vzdělávání zvyšuje konkurence. Vysoké školy jsou nuceny mezi sebou soutěžit při získávání peněžních prostředků ze státních i nestátních zdrojů. Využívají $\mathrm{k}$ tomu komercionalizaci svého duševního vlastnictví či vytváření různých spin-off firem a společných projektů $\mathrm{s}$ komerční sférou. Vzniká tak koncept univerzity jako podnikatelského subjektu. Důraz se přesouvá z vědeckého bádání na inovace, tedy ze základního na aplikovaný výzkum. U výuky je důležitá praktická uplatnitelnost nabytých poznatků, nově se rozvijí systém celoživotního vzdělávání. $Z$ pohledu místního rozvoje je důležité ukotvení a propojení univerzit, komerční oblasti a veřejné sféry z pohledu institucionálního i fyzického. Smyslem všech těchto aktivit je rozvoj znalostní ekonomiky (Benneworth, 2006).

Snaha o zvýšení konkurenceschopnosti absolventů vedla některé státy v 90 . letech 20 . stol. k integraci různých typů vysokoškolského studia do jednotné formy. ${ }^{2}$ Do integrace vysokoškolských systémů začala zasahovat také Evropská unie ve snaze vytvořit jednotný prostor vysokoškolského vzdělávání. Smyslem Boloňské deklarace (1999) je vytvoření jednotného systému vysokoškolského vzdělávání, který má vést $\mathrm{k}$ zatraktivnění studia, vyšší mobilitě studentů a větší konkurenceschopnosti absolventů na trhu práce. Spolu s rozvojem znalostní ekonomiky to je jeden z hlavních prostředků k dosažení cíle dlouhodobých strategií Evropské unie, především Evropy 2020 (2010).

\section{České vysokoškolské prostředí}

Je zřejmé, že výše popsané tendence se průběžně promítaly i do českého vysokoškolského prostředí. Nejzásadnějši změny vysokoškolského prostředí přinesl rok 1989 a s ním spojený konec komunistického režimu. Nový legislativní rámec vytvořil zákon č. 172/1990 Sb. a následně pak dosud platný zákon č. 111/1998 Sb. o vysokých školách. ${ }^{3}$ Tato legislativa je již plně v souladu se schválenou Boloňskou deklarací, která mimo jiné zavádí kreditový systém hodnocení studia a možnosti vzájemného uznávání diplomů. $\mathrm{V}$ rámci systému vysokých škol došlo $\mathrm{k}$ výrazné decentralizaci spojené se vznikem nových institucí především po roce 1999, kdy se začal vytvářet soukromý vysokoškolský sektor.

Počet vysokoškolských studentů v ČR se za posledních 20 let více než ztrojnásobil (tab. 2). České vysoké školství tak v systému M. Trowa (1974) postupně přš̌lo z elitního stupně do masového.

2 Ukázkovým př́kladem může být Velká Británie, kde došlo ke změně vysokých škol neuniverzitního typu na univerzitní (Hall, 1996).

3 V těchto normách byla upravena decentralizace řízení vysokého školství, znovuobnovení akademických svobod, podle evropského vzoru byl zaveden třístupňový systém studia, rozdělení vysoké školy na univerzitní a neuniverzitní, jasně stanoven byl systém studia a vytvořena byla pravidla pro soukromé vysoké školy. 
Tab. 1: Celkový počet vysokých škol a jejich studentů a na území ČR vobdobí 1930 až 2008

\begin{tabular}{|c|c|c|}
\hline Školní rok & Počet škol* $^{*}$ & Počet studentů** \\
\hline $1930 / 31$ & 13 & 27966 \\
\hline $1945 / 46$ & 8 & 46759 \\
\hline $1950 / 51$ & 21 & 30685 \\
\hline $1960 / 61$ & 34 & 64397 \\
\hline $1970 / 71$ & 24 & 81472 \\
\hline $1980 / 81$ & 23 & 119850 \\
\hline $1990 / 91$ & 23 & 118192 \\
\hline $2000 / 01$ & 31 & 219514 \\
\hline $2008 / 09$ & 71 & 370274 \\
\hline
\end{tabular}

* veřejné vysoké školy, od 2000/01 včetně soukromých vysokých škol

** včetně studia při zaměstnání

Rovněž v samotném Brně došlo k rapidnímu nárůstu počtu studentů, jak ukazuje tabulka 2 (přičemž nyní ponechme stranou historický vývoj, který uvedené změny doprovázel).

Tab. 2: Počty studentů na veřejných vysokých školách v Brně v období 1959 až 2011

\begin{tabular}{|l|c|c|c|c|c|c|}
\hline Rok & MU & VUT & MENDELU & VFU & JAMU & Celkem \\
\hline 1959 & 3492 & 4302 & 2819 & $*$ & 140 & $\mathbf{1 0 7 5 3}$ \\
\hline 1967 & 6430 & 9747 & 4170 & $*$ & 211 & $\mathbf{2 0 5 5 8}$ \\
\hline 1973 & 6396 & 7974 & 3214 & 611 & 195 & $\mathbf{1 8 3 9 0}$ \\
\hline 1978 & 8684 & 12268 & 4783 & 1133 & 218 & $\mathbf{2 7 0 8 6}$ \\
\hline 1985 & 7232 & 13175 & 4264 & 863 & 157 & $\mathbf{2 5 6 9 1}$ \\
\hline 1993 & 11554 & 10934 & 3670 & 1180 & 430 & $\mathbf{2 7 7 6 8}$ \\
\hline 1998 & 17101 & 14920 & 5127 & 1534 & 508 & $\mathbf{3 9 1 9 0}$ \\
\hline 2005 & 30147 & 20080 & 7842 & 2357 & 596 & $\mathbf{6 1 ~ 0 2 2}$ \\
\hline 2011 & 39742 & 22295 & 10563 & 3091 & 704 & $\mathbf{7 6 3 9 5}$ \\
\hline
\end{tabular}

* $\mathrm{v}$ uvedených letech byla VFU součástí MENDELU

\section{Modely zapojení univerzit do místního prostředí}

Jak už bylo naznačeno v části zabývající se historickým vývojem univerzit a vztahů k městům, od 80 . let se klade důraz na spolupráci univerzitního a privátního sektoru. Od 90. let pak roste snaha o napojení se na lokální instituce. V ideálním př́ípadě by tedy měla vzniknout sít' vazeb, která propojuje všechny místní aktéry a pomáhá při rozvoji celého regionu či města. Z konkrétních oblastí podle J. Goddarda (2008) vysokoškolské instituce: přispívají či hrají důležitou roli v místním rozvoji při generování př́immů v podobě daní a poplatků; (spolu)vytvářejí nové firmy a spolupracují př̀i rozvoji těch stávajících; zvyšují atraktivitu města/regionu z globálního pohledu a pomáhají přitahovat nové investice; prostřednictvím absolventů a celoživotního vzdělávání rozvíjejí a posilují místní lidský kapitál; podporují místní kulturní život. Od místního prostředí univerzity naopak potřebují: podporu při rozvoji vědy a výzkumu; pomoc při zvyšování zájmu o studium u místních uchazečů a při lákání zájemců z větších vzdáleností; dodatečné přrijmy za služby poskytované jiným sektorům jako jsou konzultace a školení; vytvoření atraktivního prostředí pro studenty a akademické pracovníky.

Schéma zapojení univerzity do regionálních struktur vytvořil J. Goddard a P. Chetterton (1999) (obr. 1). V rámci vysokoškolské instituce by mělo dojít $\mathrm{k}$ synergickému propojení jejích třech základních úkolů - výuky, výzkumu a služeb místní komunitě. Výsledkem by pak měly být dobře fungující regionální struktury produkující schopnosti a dovednosti, inovace, kulturní a komunitní zázemí. Společným zájmem obou stran je pak spolupráce vedoucí k odstraňování bariér v rozvoji. 


\section{Obr. 1: Zapojení vysokoškolské instituce do regionálních struktur}

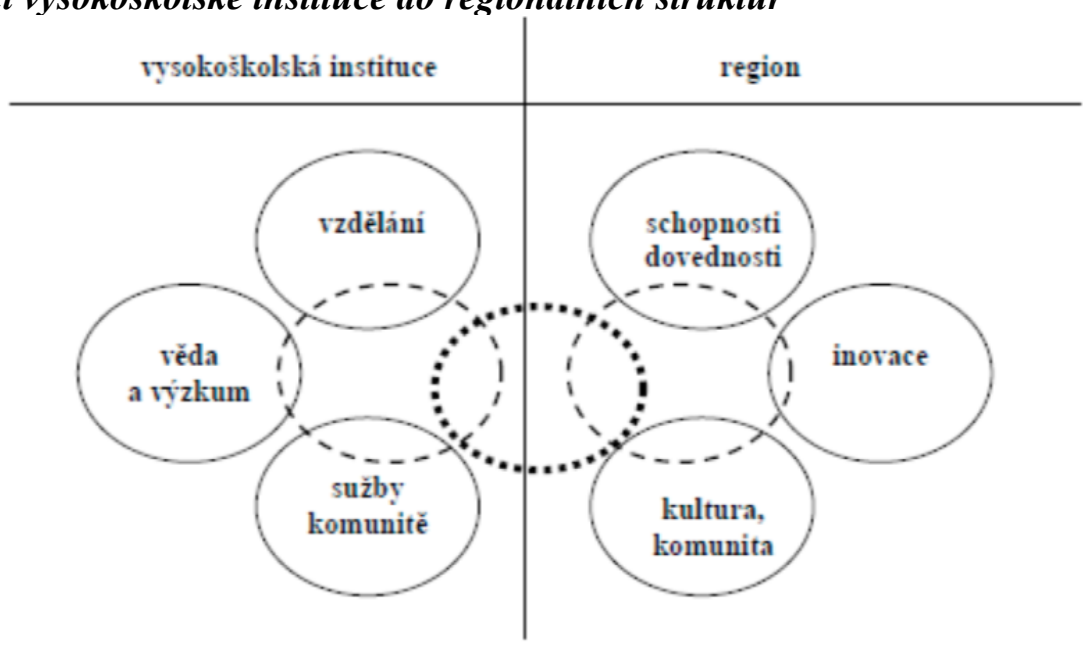

------ pridaná hodnota managementu vysokoškolských/regionálnich institucí
-...-..... prostor pro vzájemné vztahy vysokoškolské instituce a regionu

Zdroj: Goddard a Chatterton (1999)

V rámci místního rozvoje ovšem univerzita nepůsobí jako zcela nezávislá jednotka. Sama je silně ovlivňována děním na vyšších úrovních. V celostátním měřítku to jsou různé státní politiky vytvářené orgány vlády (školská, hospodářská, pracovní, regionální, sociální politika, politika vědy a výzkumu a jiné) a právní rámec daný zákony. Z globální úrovně je univerzitní prostředí pod vlivem mezinárodní akademické komunity, která hodnotí prestiž jednotlivých institucí. Důležitou roli také hrají př́ichozí investice spolurozhodující o rozvoji vysokoškolských institucí. Univerzita takto umožňuje další napojení místní úrovně na celostátní a globální struktury. Tyto vazby posilují další subjekty at' už př́mo či nepř́ímo závislé na vysokoškolském sektoru, jako jsou vědecké parky, univerzitní nemocnice nebo kulturní čtvrtě. Konkrétní podobu tohoto víceúrovňového modelu podle $\mathrm{P}$. Arba a $\mathrm{P}$. Bennewortha (2007) ukazuje obr. 2.

\section{Obr. 2: Víceúrovňový model zapojení vysokoškolské instituce do regionálního rozvoje}

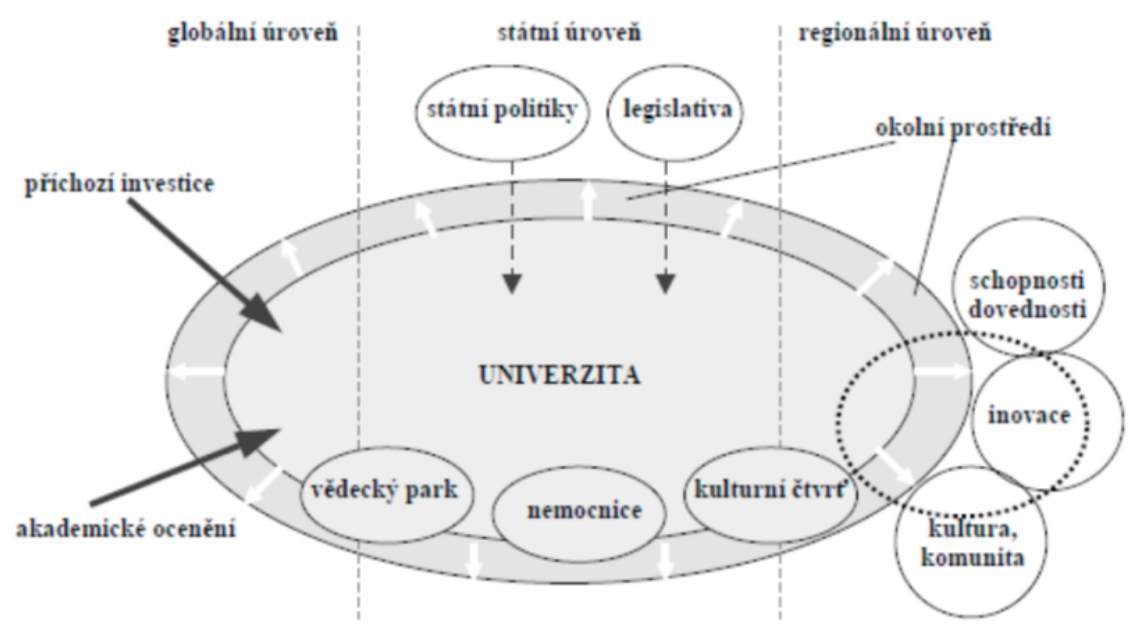

Zdroj: Arbo a Benneworth (2007)

Na postavení vysokoškolských institucí v městském rozvoji s ohledem na strategické plánování se zaměřují L. van den Berg a A. P. Russo (2003). Ti vidí atraktivní město jako magnet, který přitahuje vysoké školy a výzkum, prostřednictvím čehož dochází $\mathrm{k}$ posilování atraktivity města pro obyvatele, investory, turisty a další uživatele. Dochází tak k vytvoření uzavřeného cyklu vzájemně se posilujících 
vztahů. Předpokladem fungování tohoto cyklu je dlouhodobá rovnováha vzájemných vztahů mezi všemi aktéry (jak je zobrazeno na obr. 3).

\section{Obr. 3: Postavení vysokoškolských institucí v městském rozvoji s ohledem na možnosti strategického plánování}

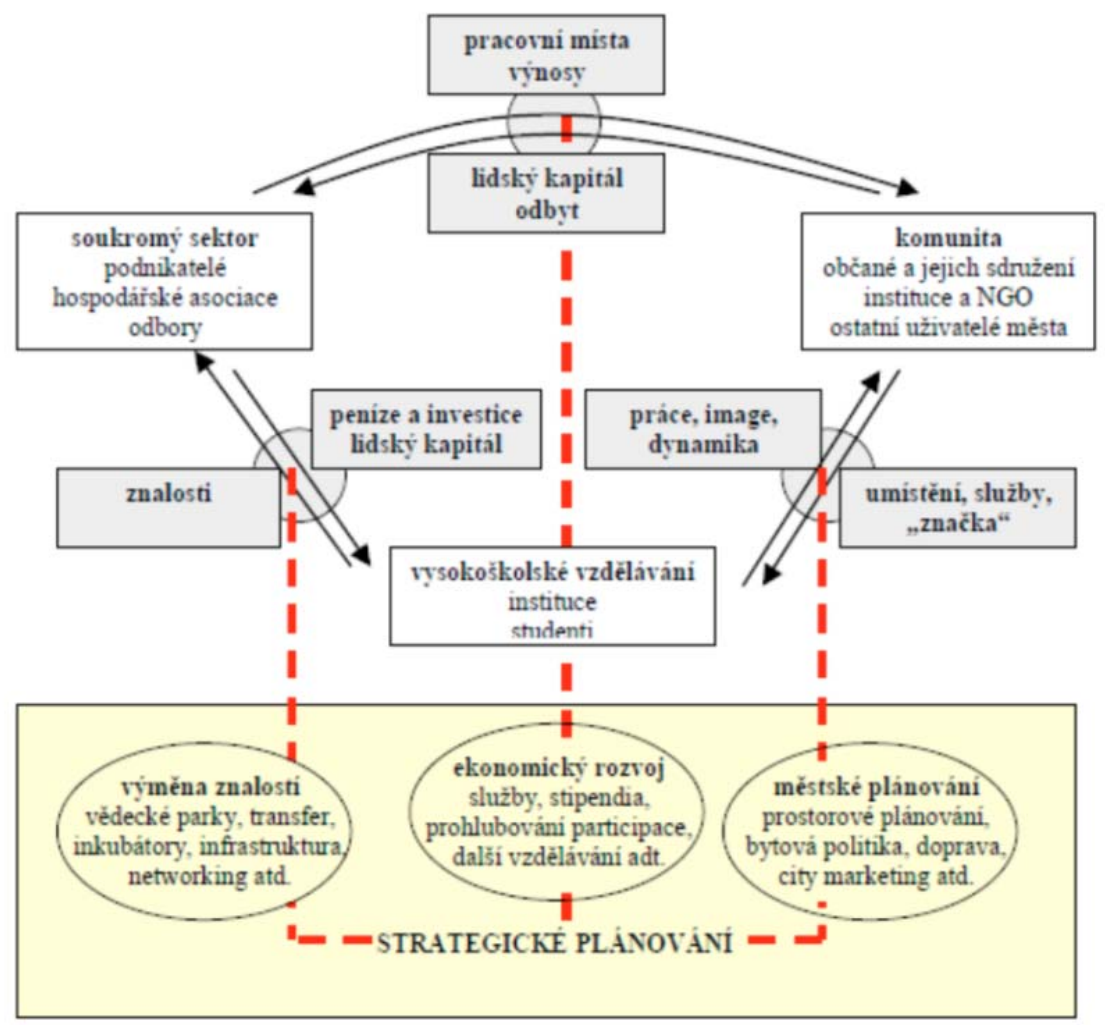

Zdroj: Van den Berg a Russo (2003)

Vysokoškolské vzdělávání je zde př́mo napojeno na soukromý sektor pomocí transferu znalostí. Školy poskytují jednotlivým podnikům jak samotné znalosti a zkušenosti prostřednictvím licencí či školení, tak kvalifikované odborníky. To je zdrojem zpětných př́ijmů a investic do vzdělávání a zkušeností z praxe. Pro vztah mezi vysokými školami a místní komunitou je klíčové prostorové ukotvení. Univerzity jako jakékoliv jiné instituce využívají městskou infrastrukturu a poptávají různé služby. Na druhou stranu pak samy služby generují a hlavně poskytují práci pro místné obyvatele. Méně viditelnou složkou těchto vztahů je pak využívání pozitivní image místa, kde univerzita může dodávat dynamiku, mladost a město naopak tradici, stabilitu a prostorové ukotvení. I poslední strana tohoto trojúhelníku, tedy vazby místní komunity se soukromým sektorem, je nepř́mo ovlivňována vysokoškolskými institucemi. Jde především o všeobecný rozvoj lidského kapitálu a zvyšování inovační kapacity. Tento proces vysílá také zpětné impulsy směrem k univerzitám. Uvedený cyklus nemůže fungovat jen na úrovni institucí. Zásadnější je zainteresování jednotlivých uživatelů - tedy studentů, akademických pracovníků či místních obyvatel, protože teprve na této úrovni dochází k vytvoření sítě pevných vzájemných vazeb. Ze strany lokálních institucí je proto nezbytné promyšlené strategické plánování, které pokryje všechny tyto oblasti.

\section{Dotazníkový průzkum}

Pro užší spolupráci mezi aktéry při tvorbě strategických dokumentů je nutné si vyjasnit některé základní otázky týkající se vzájemné interakce města a studentů. Proč si studenti vybírají Brno jako univerzitní město?; Kolik času v Brně studenti tráví?; Jak studenti bydlí a za co nejvíce utrácejí? Jak vidí svoje budoucí působení v Brně? 


\section{Metodika výzkumu a respondenti}

Pro zjišstování vzájemných interakcí a dopadů př́tomnosti studentů na rozvoj města Brna byl použit dotazník, jehož cílovou skupinou byli všichni vysokoškolští studenti studující v Brně. Dotazníkového průzkumu názorů vysokoškolských studentů na studium a život v Brně se od záŕí 2011 do ledna 2012 zúčastnilo 6020 studentů, což představuje reprezentativní vzorek. Odpovídali studenti z 12 vysokých škol v Brně. ${ }^{4}$ Na prvním místě dle odpovědí je VUT (55\% odpovědí), poté MU (22 \%) a Mendelova univerzita $(13 \%)$. Kromě studentů veřejných škol se dotazníkového průzkumu zúčastnilo také 205 studentů soukromých vysokých škol. V tabulce 3 je zobrazen počet respondentů z jednotlivých vysokých škol, z nichž se dotazníkového průzkumu zúčastnilo více než 10 studentů.

Tab. 3: Rozdělení respondentů podle vysokých škol

\begin{tabular}{|l|c|c|}
\hline \multicolumn{1}{|c|}{ vysoká škola } & $\begin{array}{c}\text { počet } \\
\text { respondentů }\end{array}$ & $\begin{array}{c}\text { podíl } \\
\text { respondentů }\end{array}$ \\
\hline VUT & 3332 & $55,3 \%$ \\
\hline MU & 1326 & $22,0 \%$ \\
\hline Mendelova univerzita & 785 & $13,0 \%$ \\
\hline VFU & 352 & $5,8 \%$ \\
\hline BIBS & 178 & $3,0 \%$ \\
\hline Univerzita obrany & 80 & $1,3 \%$ \\
\hline JAMU & 52 & $0,9 \%$ \\
\hline Akademie STING & 24 & $0,4 \%$ \\
\hline
\end{tabular}

Zdroj: vlastni dotazníkové šetření

Mezi respondenty jsou celkem rovnoměrně zastoupeni jak muži (56 \%) a ženy (44 \%), tak studenti jednotlivých ročníků. Více než polovinu respondentů tvoří studenti ve věku 18 až 22 let, 8 \% studentů je mladších než 20 let a $10 \%$ je starších než 25 let.

\section{Výsledky výzkumu}

Výzkum mezi studenty vygeneroval mnoho zajímavostí, přičemž v tomto článku budou popsány pouze vybrané charakteristiky ze života studentů, u kterých se předpokládá největší vliv na rozvoj města Brna: jde o trvalé bydliště, formu bydlení, čas, který studenti tráví v Brně, životní náklady studentů a jejich strukturu, důvod, proč studují zvolený obor právě v Brně a plány studentů po skončení současného studia s ohledem na město Brno.

88 \% respondentů má trvalé bydliště v České republice, ostatní pocházejí ze Slovenska a pouze 21 trvale bydlí v jiném státě. $Z$ místa trvalého bydliště lze usuzovat na velký zájem o studium na vysoké škole v Brně u mladých lidí z Brna a blízkého okolí, když nejvíce respondentů pochází z okresů Brnoměsto (15\%), Brno-venkov (6 \%) a dalších moravských okresů. ${ }^{5} \mathrm{Z}$ Moravy vymezené územím krajů JM, OL, ZL, MS a VY pochází přibližně dvě třetiny respondentů. Základní rozdělení studentů podle trvalého bydliště ukazuje obr. 4.

Obr. 4: Respondenti podle místa trvalého bydliště

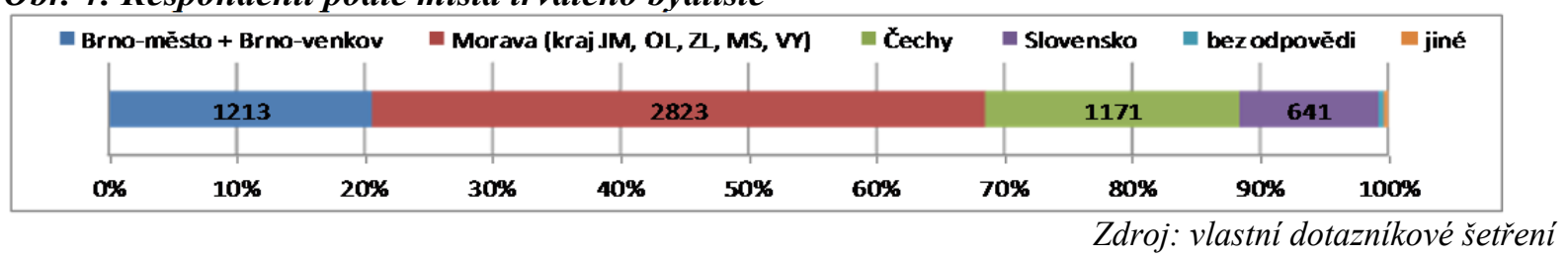

4 Nejvíce odpovědí bylo ze škol a fakult, kde všichni studenti obdrželi email z rektorátu / děkanátu se žádostí o účast. Na školách, kde toto z nejrůznějších důvodů nebylo možné, byli studenti informováni obvykle oznámením na webových stránkách.

5 Více než 2,5 \% respondentů pochází z okresů Hodonín, Žd’ár nad Sázavou, Blansko, Zlín a Břeclav. 
Co se týče formy bydlení, nejvíce studentů (více než jedna třetina) bydlí v Brně v pronajatém bytě bud' sami, nebo s více studenty a čtvrtina studentů využívá studentské koleje. Dále studenti často bydlí u rodičů $(14 \%)$ a $12 \%$ jich dojíždí do Brna z místa trvalého bydliště. Tato skutečnost velmi výrazně ovlivňuje celkovou situaci na realitním trhu ve městě Brně. Lze předpokládat, že studenti si hledají bydlení s prioritou blízkosti školy. V lokalitách s vysokou koncentrací vysokoškolských institucí existuje velmi vysoká poptávka po pronájmech bytů, která drží ceny těchto bytů na relativně vysoké úrovni. Tento jev ovlivňuje pak i okolní lokality i celé území města Brna. Na obr. 5 je patrná souvislost mezi rozmístěním vysokoškolských institucí a cenou nájmu ${ }^{6} \mathrm{v}$ bytech.

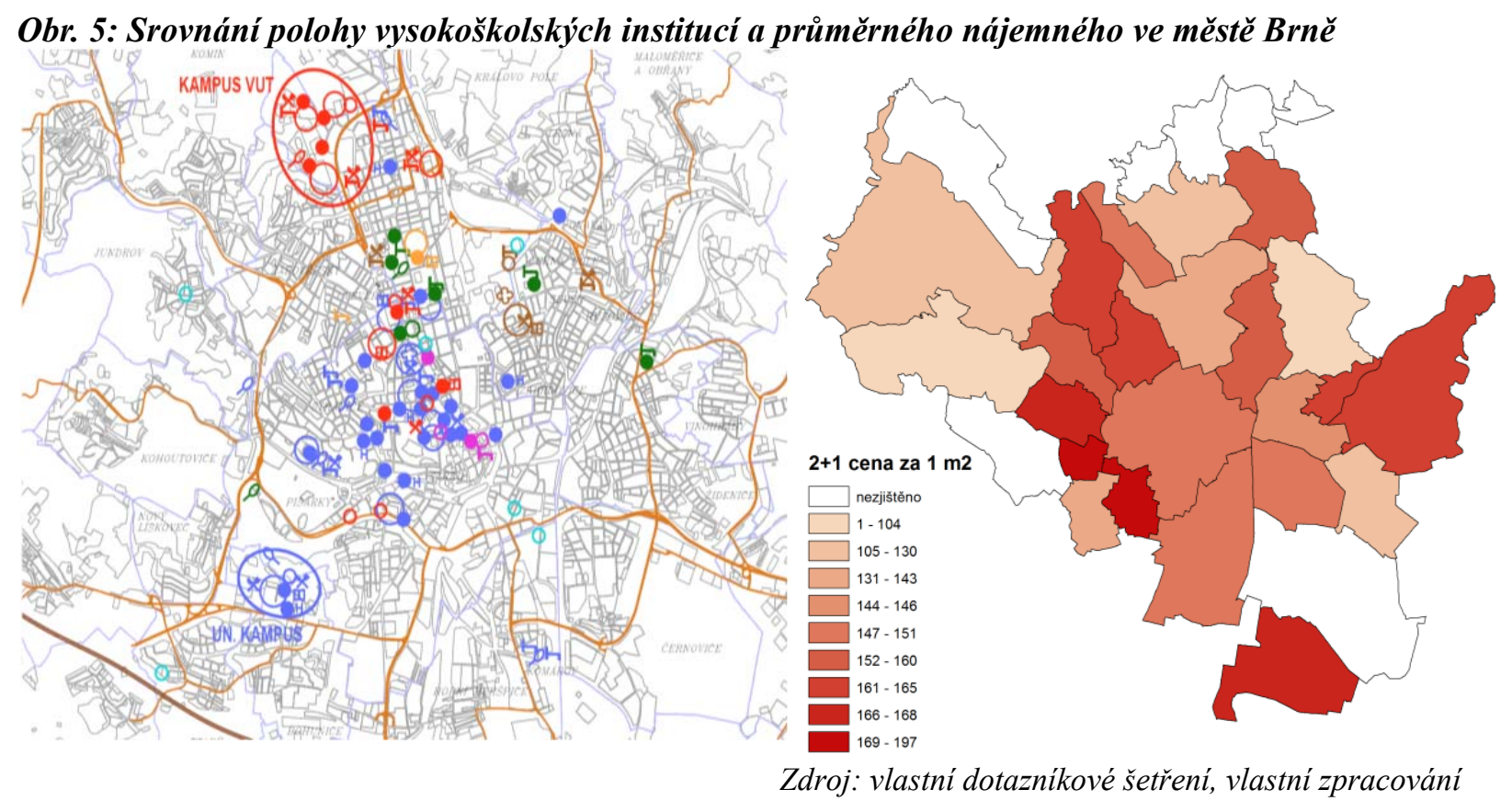

Čas, který studenti tráví v Brně v průběhu výuky a zkouškového období, je velmi závislý na tom, zda studenti v Brně trvale bydlí nebo za studiem dojíždějí. Většina studentů v Brně zůstává v průběhu výuky celý pracovní týden (65\% studentů), přičemž více než čtvrtina alespoň jeden víkendový den. Pět a více dní tráví v Brně $96 \%$ z těch, kteří mají v Brně trvalé bydliště, $67 \%$ studentů bydlících na kolejích a pouze jedna čtvrtina $\mathrm{z}$ těch, kteří dojíždějí. Relativně rovnoměrné je rozdělení studentů podle toho, kolik víkendů v měsíci pobývají v Brně. Skoro třetina studentů jezdí na všechny víkendy pryč z Brna, pouze o trochu méně naopak zůstává v Brně po tři až čtyři víkendy v měsíci. Je zde opět zřejmá závislost na místě bydliště, když tři až čtyři víkendy v měsíci v Brně tráví $82 \%$ studentů z Brna, pouze $23 \%$ studentů bydlících na kolejích a $7 \%$ z těch, kteří dojíždějí. Skoro třetina ze studentů bydlících na kolejích a dvě třetiny z těch, kteří dojíždějí, netráví v Brně žádný víkend. Během zkouškového období vzrůstá obecně podíl studentů, kteří v Brně tráví méně než tři dny v týdnu. Přesto však zůstává vysoká část těch (polovina ze všech studentů, $93 \%$ ze studentů z Brna), kteř́i v Brně pobývají celý pracovní týden, někteří včetně víkendů.

Doba strávená $\mathrm{v}$ Brně těsně souvisí s životními náklady studentů. Velikost a způsob pokrytí průměrných měsíčních životních nákladů respondentů ukazuje obr. 6 . U více než poloviny studentů se výše nákladů pohybuje mezi 5000 Kč a 7500 Kč měsíčně. Medián je 6000 Kč, tedy polovina studentů vynakládá měsíčně méně a polovina více než je tato částka. U více než poloviny studentů plně pokrývají náklady související se studiem rodiče a další př́buzní, čtvrtina studentů má dokonce plně financované životní náklady a nepotřebuje při studiu pracovat. Více než desetina studentů si musí naopak životní náklady hradit zcela sama. Jedná se tedy o nezanedbatelnou sumu, kterou v Brně studenti utrácí.

6 Průměrná cena bytu byla zjišt’ována v rámci aktualizace Indikátorové soustavy Strategie pro Brno v srpnu 2012. Jedná se konkrétně o modelový byt $2+1$ a jeho nabídkovou cenu na serveru www.sreality.cz. 
Obr. 6: Průměrné měsični životní náklady respondenti̊ a role při pokrytí těchto nákladi̊, kterou mají př́imy od rodičů (a dalších př́ibuzných)
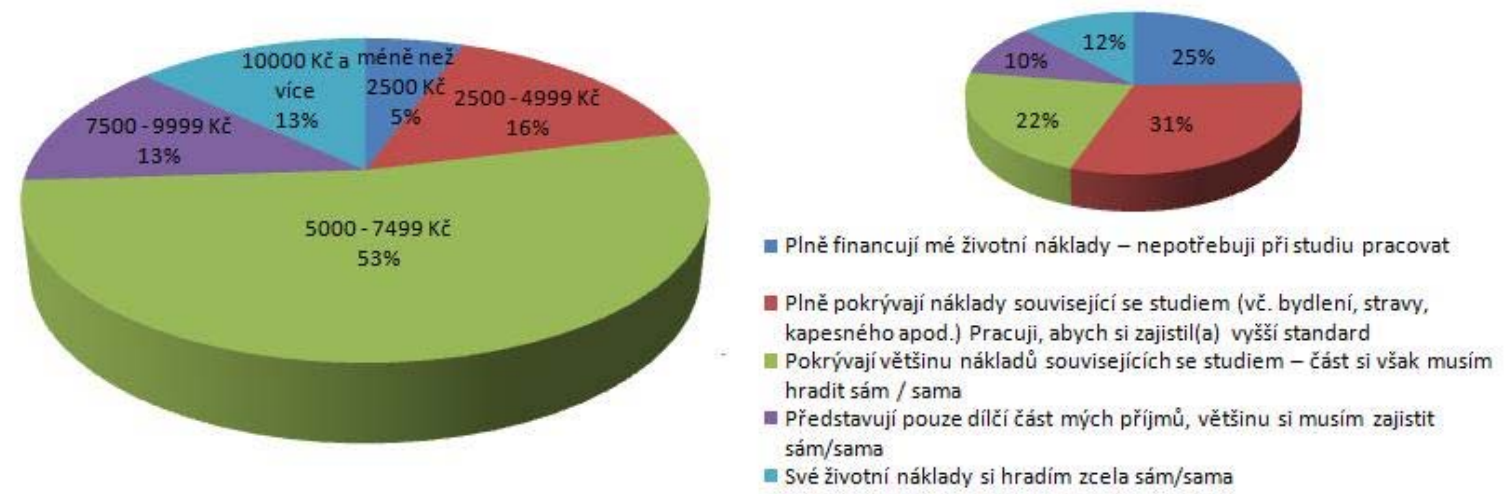

Zdroj: vlastni dotaznikové šetření

Z hlediska struktury měsíčních nákladů studenti v průměru nejvíce vydávají na bydlení ( 40 \% všech měsíčních nákladů), dále na stravování ( $25 \%)$, dopravu (10\%), ostatní aktivity $(10 \%)$ a nejméně na aktivity spojené prímo se studiem $(5 \%)$. Navíc je patrný rozdíl mezi studenty bydlícími v Brně u rodičů, kteří na bydlení nevynakládají žádné finanční prostředky (celkem $18 \%$ studentů), a těmi, kteří si bydlení v Brně financují sami a tvoří více než polovinu jejich měsíčních nákladů (tř̌etina studentů).

Jako nejvýznamnější důvod, proč studují zvolený obor právě v Brně, studenti označili skutečnost, že zvolená škola je atraktivní a má vysokou prestiž. S oběma těmito tvrzeními souhlasilo či spíše souhlasilo více než $88 \%$ ze všech dotázaných. Na dalším místě je nejlepší vzdělání v Česku, které fakulta v daném oboru nabízí, a vnímání Brna jako atraktivního města pro život, s čímž souhlasilo či spíše souhlasilo přibližně $80 \%$ studentů, jak dokládá obr. 7. Podle blízkosti k místu trvalého bydliště se rozhodla $v$ Brně studovat více než polovina studentů, což koresponduje s rozdělením studentů podle místa bydliště (viz obr. 4). S ostatními nabízenými tvrzeními studenti převážně nesouhlasili. Rovněž lze konstatovat výraznou podobnost mezi fakultami a školami u ohodnocení tvrzení, že škola je atraktivní a má vysokou prestiž. Kvalitu vzdělání a prestiž vysoké školy hodnotili v porovnání s ostatními hůře studenti soukromých vysokých škol. Na VUT, MU a Mendelově univerzitě není většinovým důvodem pro volbu studia skutečnost, že by se obor jinde v Česku nevyučoval, na rozdíl od studentů VFU.

\section{Obr. 7: Důvod zvolení studovaného oboru právě v Brně}

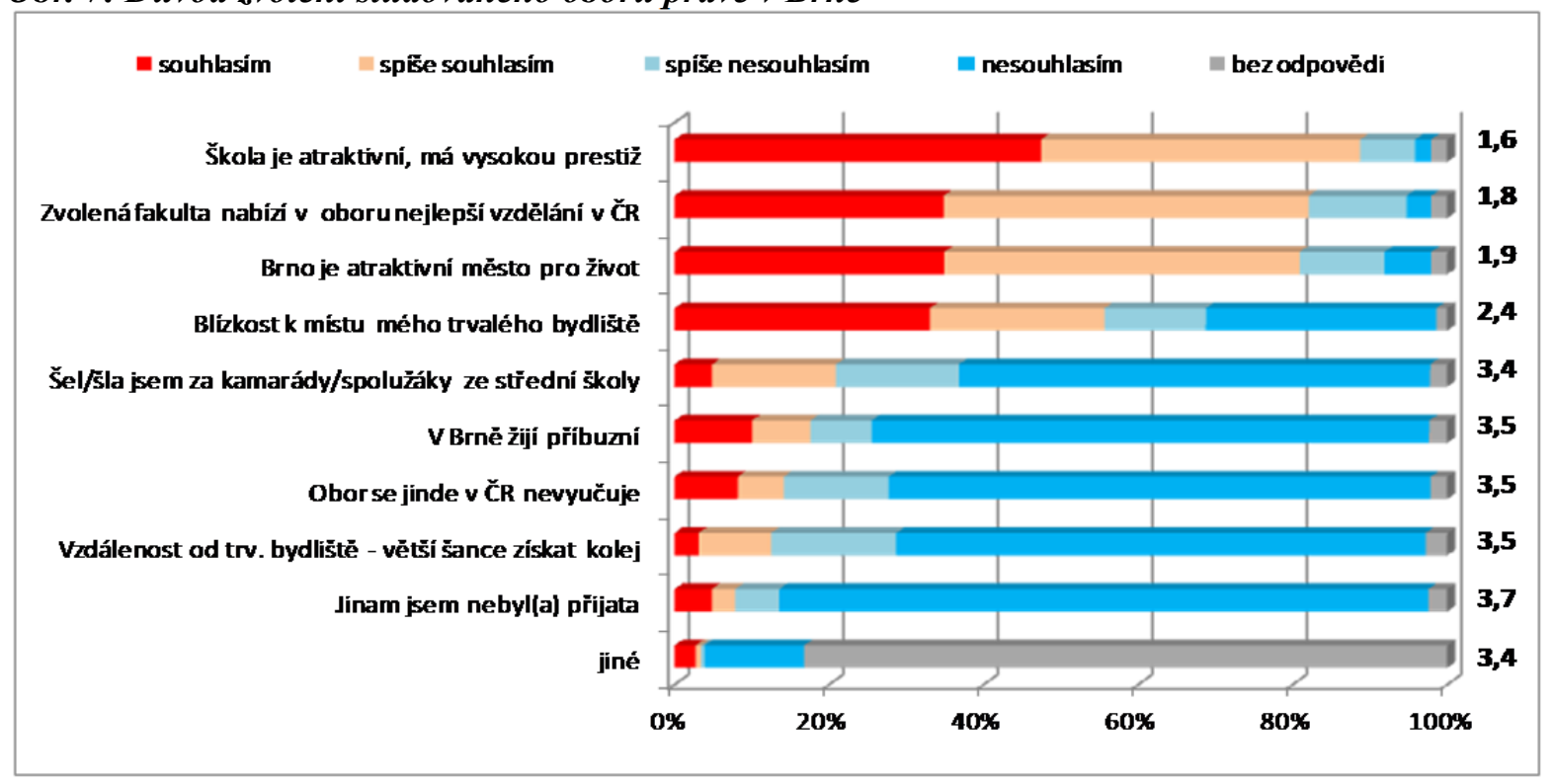

Zdroj: vlastní dotaznikové šetrení 
Při plánování své budoucnosti je velmi pozitivní skutečnost, že skoro polovina studentů chce po skončení současného studia $\mathrm{v}$ Brně zůstat, at' již z důvodu dalšího pokračování ve studiu nebo hledání práce. Jak ukazuje obr. 8 , pouze $2 \%$ studentů chtějí pokračovat ve studiu mimo Brno a $11 \%$ si chce najít práci mimo Brno. Podobné názory jsou také při odděleném pohledu na studenty VUT, MU a Mendelovy univerzity. Odlišné jsou představy o budoucnosti u studentů VFU, z nichž chce pouze malá část pokračovat dále ve studiu a více než $40 \%$ si chce najít práci mimo Brno. Představy o budoucnosti se také liší podle toho, zda studenti pocházejí z Brna či nikoliv. Zůstat v Brně chce 70 \% studentů s trvalým bydlišstěm v Brně (29\% kvůli studiu, $41 \%$ kvůli práci), přitom pouze $8 \% \mathrm{z}$ nich uvedlo, že chtějí působit jinde než v Brně. Z nebrněnských studentů chce v Brně zůstat více než polovina (30 \% kvůli studiu, $22 \%$ kvůli práci) a $17 \%$ chce působit jinde.

\section{Obr. 8: Co chtějí respondenti dělat po skončení současného studia}

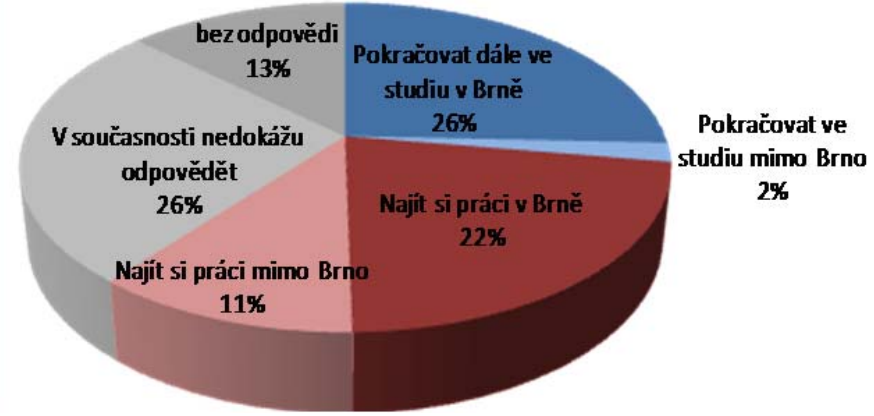

Zdroj: vlastni dotaznikové šetření

\section{Závěr}

Brno sice nepatř́i mezi centra se starobylými univerzitami, nicméně to neubírá na důležitosti, kterou po svém vzniku ve městě začaly hrát. Město je druhým největším centrem vysokého školství v České republice, jehož předností je pak především komplexnost v nabídce vysokoškolských oborů, které pokrývají všechny základní směry studia. Každodenní př́itomnost studentů se výrazným způsobem zapisuje do tváře města a to jak po stránce znalostní, tak po sociální a ekonomické.

Z výše popsaných teoretických př́stupů, ale i z výsledků dotazníku plyne, jak důležitá je kooperace mezi městem a jeho vysokými školami. Témat na spolupráci mezi městem a jeho vysokými školami, která je př́nosná pro obě strany, se nabízí hned několik. Jsou to např́klad oblasti na poli marketingu nebo života ve městě. Velmi př́nosné může být také využití energie studentů, kteří jsou aktivní a chtějí se sami angažovat pro rozvoj města. Zahrnout tato témata do strategického plánování města Brna je tady př́ímo nezbytností.

Konkrétním významným aspektem, který vyplynul z dotazníkového šetření, je fakt, že mnoho studentů má zájem zůstat v Brně i po absolvování vysoké školy. Návazně tak mohou pokračovat ve své výzkumné činnosti, př́ípadně si najít práci a usadit se trvale v Brně. To je pro město velmi výhodné, protože zde zůstává velmi vzdělaná pracovní síla důležitá pro rozvoj města. Nezanedbatelné pro zdejší ekonomiku je i to, kolik peněž zde studenti utratí př̌ studiu a trávení volného času.

Dalším nesmírně významným prvkem je fakt, že silná pozice Brna nespočívá jen v oblasti př́tomnosti vysokoškolských studentů. Město má širokou základnu také na poli vědy a výzkumu, což vytváŕí potenciál na zapojení místní ekonomiky do celosvětových struktur. Do podpory těchto vazeb se aktivně zapojují místní veřejné instituce. Město se v poslední době snaží profilovat v moderních a progresivních oblastech nanotechnologií a life sciences, které, jak věří, přinesou nový rozvoj celé místní ekonomice. Podpora mimo tyto preferované obory je výrazně slabší, což se však může do budoucna odrazit i v rozvoji jednotlivých vysokých škol. 


\section{Literatura}

[1] ALLISON, J. Over-educated, over-exuberant and over here? The impact of students on cities. Planning Practice \& Research, 2006, vol. 21, no. 1, p. 79-94. DOI: 10.1080/02697450600901541.

[2] ARBO, P., BENNEWORTH, P. Understanding the regional contribution of higher education institutions: A literature review. In OECD Education Working Paper No. 9, 2007.

[3] BENNEWORTH, P. A KOL. Tying down the 'global' in the competitive knowledge economy: university-city interactions. Newcsatle: Newcastle university, 2006. 32 p.

[4] Boloňská deklarace [online]. Společné prohlášeni ministrů školství evropských států na setkání $v$ Boloni dne 19. června 1999. Dostupné z: < http://bologna.msmt.cz/bolona-1999/bolonskadeklarace>.

[5] CONCEIÇÃ, P., HEITOR, M. V. On the role of the university in the knowledge economy. Science and Public Policy, 1999, vol. 26, no. 1, p. 37-51.

[6] ČSÚ.Historie a vývoj vysokého školství. [online]. ČSÚ, Praha, 2010. Dostupné z: $<\mathrm{http}: / /$ www.czso.cz/csu/2010edicniplan.nsf/p/3314-10>.

[7] ČSÚ. Statistická ročenka Jihomoravského kraje 2012. [online]. ČSÚ, Praha, 2012. Dostupné z: $<$ http://www.czso.cz/csu/2012edicniplan.nsf/krajp/641011-12-xb>.

[8] DELANTY, G. The Governance of Universities: What is the Role of the University in the Knowledge Society? Canadian Journal of Sociology, 2002, vol. 27, iss.2, p. 185-98. DOI: $10.2307 / 3341710$.

[9] DUKE-WILLIAMS, O. The geographies of student migration in the UK. Environment and Planning A, 2009, vol. 41, iss. 8, p. 1826-1848.

[10] ELLIOTT, S. Measuring the Economic Impact of Institutions of Higher Education. Research in Higher Education, 1988, vol. 28, no. 1, p. 17-33.

[11] Evropa $2020 \quad$ [online]. Dostupné $\quad$ z: $\quad<$ http://eurlex.europa.eu/LexUriServ/LexUriServ.do?uri=COM:2009:0347:FIN:EN:PDF >.

[12] GODDARD, J. (2008): The Role of the University in the Development of its City and Region. Přepis přednášky konané na Newcastle University ze dne 11. března 2008. 19 s.

[13] GODDARD, J.,CHATTERTON, P. Regional Development Agencies and the knowledge economy: Harnessing the potential of Universities. Environment and Planning C. 1999, No. 17, p. 685-699.

[14] HALL, P. The university and the city. GeoJournal, 1997, vol. 41, iss. 4, p. 301-309.

[15] HOLDSWORTH, C. Between two worlds: local students in higher education and 'scouse'/student identities. Population, Space and Place, 2008, no. 15, p. 225-237. DOI: $10.1002 /$ psp.511.

[16] HOLDSWORTH, C. Going away to uni': mobility, modernity, and independence of English higher education students. Environment and Planning A, 2009, vol. 41, iss. 8, p. 1849-1864.

[17] HUBBARD, P. Geographies of studentification and purpose-built student accommodation: leading separate lives? Environment and Planning A, 2009, vol. 41, iss. 8, p. 1903-1923.

[18] CHRISTINE, H. a kol. Accommodating students. Journal of Youth Studies, 2002, no. 5, p. 209235. DOI: $10.1080 / 13676260220134458$.

[19] MECHTENBERG, L., STRAUSZ, R. The Bologna process: how student mobility affects multicultural skills and educational quality. International Tax and Public Finance, 2008, vol. 15, iss. 2, p. 109-130.

[20] MOWERY, D. C. a kol. 'Ivory Tower' and Industrial Innovation: University-Industry Technology Transfer Before and After the Bayh-Dole Act. 1st. issue, Stanford University Press , Stanford, 2004. 264 p., ISBN: 978080474920687.

[21] MUNRO, M. a kol. Students in cities: a preliminary analysis of their patterns and effects. Environment and Planning A, 2009, vol. 41, iss. 8, p. 1805-1925.

[22] PERKMANN, M., WALSH, K. University-industry relationships and open innovation: Towards a research agenda. International Journal of Management Reviews, 2007, vol. 9, iss. 4, p. 259-280. DOI: $10.1111 / \mathrm{j} .1468-2370.2007 .00225 . x$. 
[23] RYBA, R. H. The Geography of Education and Educational Planning. In XXII. International Geographical Congress, Quebec, 1971, s. $1-7$.

[24] RUSSO, A. a kol. The Student City - Strategic Planning for Student Communities in EU Cities. In 43rd European Congress of the Regional Science Association, Jyväskylä, 2003.24 p. 88.

[25] SIGFRIED, J. J. a kol. The economic impact of colleges and universities. Economics of Edication Review, 2005, vol. 26, no. 5, p. 546-558. DOI: 10.1016/j.econedurev.2006.07.010.

[26] SMITH, P. D. Studentification: the gentrification factory? In Atkinson, R., Bridge, G. (eds.) The New Urban Colonialism: Gentrification in a Global Context. London: Routledge, 2005, pp 7289.

[27] SMITH, P. D. The politics of studentification and '(un)balanced' urban populations: lessons for gentrification and sustainable communities?' Urban Studies, 2008, no. 45, p. 2541- 2564.

[28] SMITH, P. D. 'Student geographies', urban restructuring, and the expansion of higher education. Environment and Planning A, 2009, vol. 41, iss. 8, str. 1795-1804.

[29] SCHOFER, J. P. Determining Optimal College Locations. Higher Education, 1975, vol. 1975, iss. 4, p. 227-232.

[30] TROW, M. Problems in transition from elite to mass higher education. OECD, Paříž 1974. In Teorie vzděláváni ve vyspělých zemích: vývoj a současnost. Středisko vzdělávací poltiky, PaedF UK, Praha, 1997. $138 \mathrm{~s}$.

[31] VAN DEN BERG, L., RUSSO, A. P. The Student City. Strategic Planning for Student Communities in EU Cities. European Regional Science Association, Viena, 2003.

[32] WATERS, J. L. In pursuit of scarcity: transnational students, 'employability', and the MBA. Environment and Planning A, 2009, vol. 41, iss. 8, p. 1865-1873.

Článek vznikl částečně na podkladech zprojektu Rozvojové dokumenty Strategie pro Brno, CZ.1.04/4.1.01/53.00084. Úplné výsledky dotazníkového šetrení mají autoři k dispozici. 